\section{POLISH PUBLICATIONS ON JUJUTSU (1906- 2020): BIBLIOMETRIC ANALYSIS}

\author{
PUBLICAÇÕES POLONESAS SOBRE JIU-JÍTSU (1906-2020): ANÁLISE \\ BIBLIOMÉTRICA C्.
}

PUBLICACIONES POLACAS SOBRE JUJUTSU (1906-2020): ANÁLISIS BIBLIOMÉTRICO Cे

https://doi.org/10.22456/1982-8918.111543

Mikel Pérez-Gutiérrez* <mikel.perez@unican.es>

Paweł Świder** <pol1977@op.pl>

Jacek Kulpiński** <qlax@wp.pl>

Wojciech J. Cynarski ${ }^{* *}<$ ela_cyn@wp.pl>

*University of Cantabria, Santander, Espanha

**University of Rzeszow, Rzeszow, Polonia.

\begin{abstract}
The aim was to perform a bibliometric analysis of Polish jujutsu publications focused on productivity, topics, and collaboration. Thus, the National Library of Poland, Polish Scientific Journals Database, Web of Science and Scopus were consulted. Results were filtered and exported to Excel 2016 for statistical analysis. 123 Polish jujutsu documents were published from 1906 to 2020. Life Sciences had the highest representation, while collaboration predominated during the last decade. Cynarski was the most productive author, while Wojdat achieved the highest collaboration index. Ido Movement for Culture was the main source for disseminating these publications. In conclusion, technical books written by single authors from a Life Sciences approach prevailed in Polish jujutsu publications during the $20^{\text {th }}$ century, while scientific articles written in collaboration and also representing other approaches have prevailed in the $21^{\text {st }}$ century.
\end{abstract}

Keywords: Bibliometrics. Martial Arts. Publications. History.
Received in: 11 Mar. 2021 Approved in: 13 Sep. 2021 Published in: 10 Nov. 2021

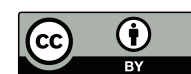

This is an article published in open access under the Creative Commons Attribution 4.0 (CC BY 4.0) eISSN: 1982-8918 


\section{INTRODUCTION}

The General Theory of Fighting Arts (GTFA) (CYNARSKI, 2019) was adopted as the scientific framework, considering "Fighting arts" a collective term for various martial arts, combat sports, combat systems, self-defence systems, fencing, handto-hand combat, etc. In this way, from the perspective of the Humanistic Theory of Martial Arts and GTFA, martial arts were defined as a historic category of flawless methods of unarmed combat fighting and the use of weapons, combined with spiritual elements (both personal development and in the transcendental sphere) (CYNARSKI, 2004; CYNARSKI; SKOWRON, 2014). Despite the term jujitsu is commonly used in scientific literature (PÉREZ-GUTIÉRREZ; GUTIÉRREZ-GARCÍA; ESCOBARMOLINA, 2011), different spellings are used and accepted for jujutsu (CYNARSKI, 2000). There also appear inconsistencies within the same publication, using jujitsu in the title and jujutsu when giving examples of methods (CRAIG, 1995). However, the spelling jujutsu is the proper transcription from Japanese, literally meaning art of flexibility (GREEN; SVINTH, 2010) but, according to GTFA, it relates to: "1) martial arts performing the principle of 'jū'; 2) Japanese hand-to-hand martial arts; 3) in general related methods of self-defence (goshinjutsu); 4) "sports" jūjutsu, combined with judo, karate or kick-boxing" (CYNARSKI; SKOWRON, 2014, p. 20).

The history of jujutsu in Poland dates back to 1904 with the publication of the first information about it in Poland in the Polish language. In this year, three books and one article including information about jujutsu were published. Books titled Japan and the Japanese (OKSZYC, 1904), The Contemporary Japan (WEULERSSE, 1904), and Bushido- the Soul of Japan (NITOBE, 1904), as well as an article titled The Physical Education in Japan published in three different journals (PIASECKI, 1904a, 1904b, 1904c), presented this martial art to Poles, triggering their interest about it. This turning point was celebrated in 2004 with the development of the Historical Convention of Polish Jujutsu Masters, which included a training seminar and scientific conference for commemorating 100 years of jujutsu history in Poland (CYNARSKI, 2007).

Most of the books published in Poland before World War II showed jujutsu in a form reduced to a set of self-defence techniques, mainly used in training the police and the army among others. The more famous instructors and specialists from that period include Laskowski, Sikorski, Jeziorowski and Pawełek, as well as the Japanese inspector Kuwashima (GRZEGORZ; WALENDOWICZ, 2008). However, one of the first promoters of jujutsu in Poland was a sports activist, Zygmunt Kłośnik, who published a jujutsu book in two different editions (HANCOCK; KŁOŚNIK, 1907, 1909) presenting it as a form of physical culture, not just a set of self-defence techniques, broadening its approaches.

After World War II and up to 1989, a strictly utilitarian approach was dominant, involving the use of jujutsu techniques primarily for self-defence situations. Publications presenting this application of jujutsu techniques were often called differently as judo, self-defence, defensive tricks, etc. (CYNARSKI, 2008). During this period, Dr. Kondratowicz organized from 1974 to 1984 a youth "self-defence jiu-jitsu" section in Nowy Dwór Mazowiecki. From that time onwards, the institutionalization and organizational development of jujutsu in Poland gradually followed. In 1985, 
the National Council of Jujutsu Martial Arts Instructors was established. In 1990, the Polish JuJitsu Federation in Kraków and the Polish Jujutsu Academy in Zielona Góra were registered. In 1993, Idokan Poland Association in Rzeszow, the Polish Jujutsu Association in Katowice, and the Polish Jujutsu Organisation in Jaworzno were created. In addition, the International Modern Ju-Jitsu Federation was registered in Głogów in 1996 (CYNARSKI; BAJOREK, 2011; CYNARSKI; SIEKANSKI, 2019).

The study of martial arts and combat sports publications has been developed in different countries by means of bibliometric, bibliographic or content analysis. In Spain, Pérez-Gutiérrez and Gutiérrez-García (2009) carried out a bibliometric analysis of the martial arts and combat sports monographs published from 1906 to 2006; Gutiérrez-García and Pérez-Gutiérrez (2009a) described the features and contents of the earliest books on martial arts published in Spanish; and Gutiérrez-García and Pérez-Gutiérrez (2009b) analyzed the doctoral theses, scientific books and articles in martial arts published from 1990 to 2008. In Czech Republic, Čihounková and Reguli (2011) performed a bibliometric analysis of karate books, while Vit and Reguli (2011) described the Czech books focused on combatives and self-defence from 1873 to 2009. In Poland, Cynarski (2001) presented a general critical analysis of both scientific and popular publications on martial arts, which also applies to jujutsu. Later, he evaluated the literature on jujutsu and self-defence in the Polish People's Republic (years 1945-1989) (CYNARSKI, 2008). Moreover, other Polish reviews and discussions of combat sports literature were concerned with fencing, describing the fencing bibliography in $19^{\text {th }}$ and $20^{\text {th }}$ century (SZAJNA, 2007) and scholarly studies on fencing during the $21^{\text {st }}$ century (LUCZAK, 2015). Thus, the aim of the present study was to perform a bibliometric analysis of Polish jujutsu publications focused on the aspects of productivity, topics and collaboration. Therefore, an overview of the evolution of these publications, their type of document, character, field of science and authorship's features, as well as the collaboration patterns of their authors and the main sources used for publishing them is presented.

\section{METHOD}

Polish documents focused on jujutsu and published until 2020 were included in the present study. Thus, documents written by Polish authors or publish by Polish journals and publishers were collected. Regarding document type, articles, books and book chapters were only considered. These documents should be focused on jujutsu as their main topic.

\subsection{Data retrieval}

The National Library of Poland, the Polish Scientific Journals Database as well as the main international databases such as Web of Science and Scopus were consulted for data mining, following a similar methodology used by Pérez-Gutiérrez and Gutiérrez-García (2011) for the preparation of an Asian martial arts monographs bibliography. The recommendations of Pérez-Gutiérrez, Gutiérrez-Garcia and Escobar-Molina (2011) were also attended for introducing manually the different terms and spellings (jujitsu, jujutsu, jiu jitsu, ju jitsu, ju jutsu) referring to jujutsu. Obtained 
results were individually analysed to determine their relevance and then included in Excel 2016 for statistical analysis.

\subsection{Data analysis}

Data analysis was focused on the bibliometric analysis of productivity, topics and collaboration (LÓPEZ LÓPEZ, 1996). Regarding productivity, documents were distributed by decade, type of document, journal/publisher, as well as their character as scientific or technical. In relation to topics, documents were classified by their field of science and technology following the UNESCO nomenclature (SIMPLE KNOWLEDGE ORGANIZATION SYSTEM, 2021) and distributed by decade.

Relating to collaboration patterns, single-authored documents (SA), multiauthored documents (MA), mean of authors per document and percentage of collaboration $(\% \mathrm{C})$ were calculated and distributed per decade. Percentage of collaboration $(\% \mathrm{C})$ was calculated using the formula given by Valenciano Valcárcel et al. (2010), being $\% C=M A / M A+S A$. The number of documents, signatures, collaborators and collaboration index were calculated for those authors with more than three documents, also including their current institutional affiliation. Collaboration index was calculated as the ratio of signatures to documents.

\section{RESULTS}

Polish documents focused on jujutsu achieved 123, published from the beginning of the $20^{\text {th }}$ century to 2018. Articles and books were the most important documents for the dissemination of knowledge about it with 69 and 48 respectively. These documents were mainly published during the last three decades, predominating the scientific character (Table 1).

Table 1 - Distribution of articles, books and book chapters by decade

\begin{tabular}{|c|c|c|c|c|c|c|}
\hline \multirow{2}{*}{ Decade } & \multicolumn{2}{|c|}{ Article } & \multicolumn{2}{|c|}{ Book } & \multicolumn{2}{|c|}{ Book chapter } \\
\hline & Sci. & Tech. & Sci. & Tech. & Sci. & Tech. \\
\hline 1900-1909 & & & & 2 & & \\
\hline \multicolumn{7}{|l|}{$1910-1919$} \\
\hline $1920-1929$ & & & & 2 & & \\
\hline 1930-1939 & & & 1 & 1 & & \\
\hline 1940-1949 & & & & 2 & & \\
\hline 1950-1959 & & & & 1 & & \\
\hline 1960-1969 & & & & 8 & & \\
\hline \multicolumn{7}{|l|}{$1970-1979$} \\
\hline 1980-1989 & & & & 3 & & \\
\hline 1990-1999 & 1 & & 1 & 4 & & \\
\hline 2000-2009 & 16 & & 4 & 9 & 4 & \\
\hline 2010-2019 & 50 & 2 & 6 & 4 & 2 & \\
\hline Total & 67 & 2 & 12 & 36 & 6 & \\
\hline
\end{tabular}

Sci.: Scientific, Tech.: Technical. 
From the 24 fields of science and technology declared by UNESCO, Polish jujutsu documents were just approached from six of them, but principally from Life Sciences. On the contrary, Pedagogy was only represented in two documents (Table 2).

Table 2 - Distribution of documents by field of science and technology and decade

\begin{tabular}{|c|c|c|c|c|c|c|}
\hline Decade & Anthropology & History & Life Sciences & Pedagogy & Psychology & Sociology \\
\hline 1900-1909 & & & 1 & 1 & & \\
\hline \multicolumn{7}{|l|}{$1910-1919$} \\
\hline $1920-1929$ & & & 2 & & & \\
\hline $1930-1939$ & & & 2 & & & \\
\hline 1940-1949 & & & 2 & & & \\
\hline 1950-1959 & & & 1 & & & \\
\hline 1960-1969 & & & 8 & & & \\
\hline \multicolumn{7}{|l|}{$1970-1979$} \\
\hline 1980-1989 & & & 3 & & & \\
\hline 1990-1999 & & & 6 & & & \\
\hline 2000-2009 & 3 & & 28 & & 2 & \\
\hline 2010-2019 & 1 & 5 & 40 & 1 & 11 & 6 \\
\hline Total & 4 & 5 & 93 & 2 & 13 & 6 \\
\hline
\end{tabular}

Source: research data.

As shown in Table 3, the amount of single- and multi-authored documents showed an irregular development along time. However, there was an increase in the number of multi-authored articles, the mean of authors per article and the percentage of collaboration during the last three decades.

Table 3 - Distribution of the amount of single-authored documents, multi-authored documents, mean of authors per document and percentage of collaboration per decade

\begin{tabular}{ccccc}
\hline Decade & $\begin{array}{c}\text { Single-authored } \\
\text { documents }\end{array}$ & $\begin{array}{c}\text { Multi-authored } \\
\text { documents }\end{array}$ & $\begin{array}{c}\text { Mean authors/ } \\
\text { document }\end{array}$ & $\% \mathbf{C}$ \\
\hline $1900-1909$ & 1 & 1 & 1.5 & 50 \\
$1910-1919$ & & 2 & 2.5 & 100 \\
$1920-1929$ & 2 & & 1 & 0 \\
$1930-1939$ & 2 & 1 & 1 & 0 \\
$1940-1949$ & & 5 & 2 & 100 \\
$1950-1959$ & 3 & & 1.63 & 62.5 \\
$1960-1969$ & & & & \\
$1970-1979$ & 3 & 1 & 1.14 & 0 \\
$1980-1989$ & 6 & 13 & 1.48 & 39.29 \\
$1990-1999$ & 20 & 50 & 3.5 & 78.13 \\
$2000-2009$ & 14 & & & \\
$2010-2019$ & & & & \\
\hline
\end{tabular}

Source: research data.

The collaboration patterns exhibited by the most productive authors are shown in Table 4. Cynarski was the most productive scholar, who also achieved the 
highest number of signatures (46) and the most extensive collaboration network with 17 collaborators. On the contrary, Wojdat (5.25) achieved the highest collaboration index publishing only four documents. A research group about jujutsu is located in the University School of Physical Education in Krakow, since two authors were affiliated to this institution.

Table 4 - Most productive authors (>3 documents), with their current institutional affiliation and collaboration patterns

\begin{tabular}{|c|c|c|c|c|c|}
\hline Author & Docs. & Sig. & $\begin{array}{l}\text { Collab. } \\
\text { index }\end{array}$ & Collab. & Institutional affiliation \\
\hline Cynarski, W. J. & 27 & 46 & 1.70 & 17 & University of Rzeszow \\
\hline Ambroży, T. & 10 & 33 & 3.30 & 15 & $\begin{array}{c}\text { University School of Physical } \\
\text { Education in Krakow }\end{array}$ \\
\hline Haesendonck, F. M. Van. & 6 & 12 & 2.00 & 2 & Private teacher and trainer \\
\hline Kondratowicz, K. & 6 & 6 & 1.00 & 0 & Private teacher and trainer \\
\hline Słopecki, J. & 6 & 8 & 1.33 & 2 & European Martial Arts Committee \\
\hline Sterkowicz-Przybycień, K. & 5 & 9 & 1.80 & 3 & $\begin{array}{c}\text { University School of Physical } \\
\text { Education in Krakow }\end{array}$ \\
\hline Wojciechowski, B. & 5 & 10 & 2.00 & 1 & Translator for Mr Haesendonck \\
\hline Piwowarski, J. & 4 & 15 & 3.75 & 8 & $\begin{array}{c}\text { School of Higher Education in Public } \\
\text { and Individual Security "Apeiron" in } \\
\text { Krakow }\end{array}$ \\
\hline Wojdat, M. & 4 & 21 & 5.25 & 11 & Kazimierz Wielki University \\
\hline
\end{tabular}

Docs: documents; Sig.: signatures; Collab. Index: collaboration index; Collab.: collaborators Source: research data.

Finally, 60 sources were found for disseminating Polish publications on jujutsu (Table 5). However, two journals, Ido Movement for Culture and Archives of Budo, collected $26.45 \%$ of total publications. Within the top five sources list also appeared two publishers such as Sport i Turystyka and Gdansk University of Physical Education and Sports, as well as the journal titled Archives of Budo Science of Martial Arts and Extreme Sports.

Table 5 - Top sources for the dissemination of Polish jujutsu documents

\begin{tabular}{ccc}
\hline Source & $\mathbf{n}$ & \% \\
\hline Ido Movement for Culture & 19 & 15.32 \\
Archives of Budo & 13 & 10.48 \\
Wydawnictwo "Sport i Turystyka" & 9 & 7.26 \\
Archives of Budo Science of Martial Arts and Extreme Sports & 5 & 4.03 \\
Gdansk University of Physical Education and Sports & 4 & 3.23 \\
Journal of Education, Health and Sport & 4 & 3.23 \\
Journal of Combat Sports and Martial Arts & 3 & 2.42 \\
Journal of Human Kinetics & 3 & 2.42 \\
11 journals with 2 documents & 22 & 17.74 \\
41 journals with 1 document & 41 & 33.06 \\
\hline
\end{tabular}

Source: research data. 


\section{DISCUSSION}

The total amount of Polish documents focused on jujutsu was 123. The dissemination of knowledge about jujutsu started in 1906, with the publication of the book written by Shozo Kuwashima, the Japanese inspector in Poland, titled "JiuJitsu: japońska metoda walki zapaśniczej”. Although articles were the main type of documents for studying jujutsu (Table 1), until 1980s there was a predominance of technical books focused on presenting the progressive learning of their several techniques (HAESENDONCK; WOJCIECHOWSKI, 1960a, 1960b, 1961a, 1961b, 1961c) and their application to self-defence situations (JEZIOROWSKI; OSMOLSKI, 1923; OSAKA, 1935). A similar situation was observed in Spain regarding the development of Asian martial arts monographs (GUTIÉRREZ-GARCÍA; PÉREZGUTIÉRREZ, 2009a; PÉREZ-GUTIÉRREZ; GUTIÉRREZ-GARCÍA, 2008) and in Czech Republic pertaining combative and self-defence (VIT; REGULI, 2011) as well as karate books (ČIHOUNKOVÁ; REGULI, 2011).

Thus, the predominance of books was followed by the progressive increase of studies and investigations about those martial arts and combat sports, together with their publication in scientific or technical journals for strengthening the understanding about them. While the pioneering time was especially a period of fascination with the effectiveness of combat techniques (GRZEGORZ; WALENDOWICZ, 2008), at the stage of advanced institutionalization specialist issues appeared in separate studies. From the 1990s onwards, the establishment of several jujutsu organizations (CYNARSKI; BAJOREK, 2011; CYNARSKI; SIEKANSKI, 2019) as well as the appearance of two scientific journals such as Ido Movement for Culture in 2000 (IMC JOURNAL, 2021a) and Archives of Budo in 2005 (ARCHIVES OF BUDO, 2021) reflected the social and academic interest of practitioners and scholars on martial arts and combat sports in general, but also triggered the publication of articles about them, including jujutsu.

These results could be partially compared with the study carried out by Pérez-Gutiérrez and Gutiérrez-García (2008) focused on martial arts monographs published in Spain. These authors found 307 judo and jujutsu monographs published from 1950s onwards. The inclusion of judo together with jujutsu monographs should explain the difference between results, since judo showed an important social and sporting development after its inclusion within the Tokyo 1964 Olympic Games (INTERNATIONAL JUDO FEDERATION, 2021). Moreover, Gutiérrez-García and Pérez-Gutiérrez (2009a) discovered most of the earliest martial arts books published in Spain were focused on jujutsu, being the first one published in 1906 by Emile André as a translation of its French edition. As it was mentioned, the first Polish jujutsu book was published in the same date, so future studies should analyze the history and development of Spanish, Czech and Polish jujutsu books for discovering similarities about their publication features and contents. In Czech Republic, despite combative and self-defence literature started at the end of the $19^{\text {th }}$ century, most of these publications appeared from the 1950s onwards (VIT; REGULI, 2011), while karate books were published after the regime change in 1989 (ČIHOUNKOVÁ; REGULI, 2011). 
Regarding the approaches shown in Polish jujutsu documents, six different fields were represented, most of them appearing during the last two decades. Life Sciences was the main field of knowledge (Table 2). Considering there are 24 fields declared by UNESCO (SIMPLE KNOWLEDGE ORGANIZATION SYSTEM, 2021), some gaps of knowledge and approaches are detected. Thus, scholars and academics should extend the understanding about jujutsu, incorporating knowledge from fields such as Philosophy, Ethics or Medical Sciences among others, for explaining the philosophical foundations of Polish jujutsu, reflecting about the use of jujutsu in selfdefence situations or analyzing the most common injuries associated with its practice. Furthermore, the predominance of Life Sciences has been also corroborated in other sports such as futsal (PALAZÓN; ORTEGA; GARCÍA-ANGULO, 2015), handball (PRIETO; GÓMEZ; SAMPAIO, 2015) or surfing (PÉREZ-GUTIÉRREZ; COBOCORRALES, 2020), other martial arts such as taekwondo (PÉREZ-GUTIÉRREZ et al., 2017), as well as in sport sciences in general (ANDRADE et al., 2013; PÉREZ-GUTIÉRREZ; COBO-CORRALES; IZQUIERDO-MACÓN, 2018; PÉREZGUTIÉRREZ; LAGOS-HERNÁNDEZ; IZQUIERDO-MACÓN, 2016). In this way, present results are corroborating this trend towards life sciences' approach.

These results should be understood within the development of Physical Education in Poland. Jujutsu before World War I was perceived as a method of body training and its utilitarian approach was peripheral. In the period between the World Wars, jujutsu was perceived in two different ways. Firstly, it was valued as a form of wrestling, focusing on its educational advantages and influence on fitness, being consistent with the development of Polish thought in the field of physical education theory (CYNARSKI, 2014). Secondly, it was appreciated due to its utilitarian virtues, being practiced in military and police circles (GRZEGORZ; WALENDOWICZ, 2008). Therefore, jujutsu publications were reflecting the social, cultural and academic development of Physical Education in Poland during that period.

After World War II, jujutsu was also taught mainly for its utilitarian values, as a form of self-defence. These results are in accordance with the situation of Physical Education. Poland was still under the political influence of the Soviet Union and Physical Education was directed towards sport/physical training, "developing an individual into a strong and physically fit "subject" able to defend his or her country" (BRONIKOWSKI, 2014, p. 371). It was only after 1989 that sports jujutsu was developed in Poland, together with the scientific research on jujutsu, reflecting the gradual institutionalization and organizational development of jujutsu in Poland (CYNARSKI; BAJOREK, 2011; CYNARSKI; SIEKANSKI, 2019).

In relation to collaboration, Table 3 showed an irregular development of singleauthored and multi-authored documents along time and a progressive increase of the percentage of collaboration and means of authors per document during the last three decades. Collaboration among authors was strongly developed during the last decade, presenting a predominance of multi-authored articles but also a mean of 3.5 authors per document and achieving a 78\% of collaboration, confirming the results obtained within sport sciences in particular (WANG; THIJS; GLÄNZEL, 2015) and science in general (PRICE, 1986). 
The collaboration patterns shown by the most productive authors (Table 4) differed substantially among them. Productivity and collaboration were not directly related, since Cynarski was the most productive author with the most extensive collaboration network (17 collaborators) but he achieved a collaboration index of 1.70. On the other hand, Wojdat achieved the highest collaboration index (5.25) with only four documents published. However, those authors affiliated to a higher education institution showed a trend to collaborative work, a typical aspect of scientific research for sharing responsibilities and improving quality (KYVIK; REYMERT, 2017). The rest of authors, Haesendonck, Kondratowicz and Wojciechowski, presented a lower number of collaborators due to they were teachers and wrote books for explaining jujutsu fundamentals, so collaboration was only necessary for translation to Polish language since Haesendonck was Belgian.

Despite the methodological differences between the present work and those studies focused on the scientific literature indexed in the Web of Science about taekwondo (PÉREZ-GUTIÉRREZ et al., 2017) and judo (PESET et al., 2013), as well as their time span finishing in 2016 and 2011 respectively, the results could be compared. The present work checked the Web of Science for retrieving scientific literature, but also other sources of information for widening data retrieval and including other document types and languages. Scopus was included due to its large and multidisciplinary coverage (GUSENBAUER; HADDAWAY, 2020), while the National Library of Poland and the Polish Scientific Journals Database were consulted for retrieving polish books and book chapters and scientific literature published in Polish, respectively. These differences have probably emphasized the role, output and collaboration patterns exhibited by Polish authors.

In the present study, Cynarski was clearly the most productive author with 27 documents, while Pieter collected 19 articles about taekwondo (PÉREZGUTIÉRREZ et al., 2017) and Franchini compiled 18 papers on judo (PESET et al., 2013). However, Pieter and Franchini collaborated with more authors than Cynarski, with 43 and 32 collaborators respectively, and achieved a higher collaboration index, 3.26 and 3.56, respectively. Thus, the leading role of Cynarski within Polish jujutsu documents is mainly due to the development of single-authored articles. However, the scope and methodological process of the present work emphasize the actual role and contribution of Polish authors, considering the publication of books, book chapters and articles that are not only indexed in the Web of Science. Moreover, the inclusion of technical documents increases the output of authors, but it provides a more accurate overview of the contributions of Polish authors to the understanding of jujutsu.

The physiological orientation of the papers written by Pieter (DO KIM; PIETER, 2020; DO KIM; PIETER; BERCADES, 2018) and Franchini (FRANCHINI; DUNN; TAKITO, 2020; OUERGUI et al., 2020) should explain their more extensive collaboration networks since collaboration is usually higher in Life Sciences than in Social Sciences (BORDONS; GÓMEZ, 2000).

Moreover, the collaboration index within taekwondo articles ranged from 1.36 to 7.22 (PÉREZ-GUTIÉRREZ et al., 2017) while in judo literature varied between 
2.71 and 7.17 (PESET et al., 2013). The collaboration index observed in Polish jujutsu documents was between 1 and 5.25, with several authors such as Słopecki, Cynarski and Sterkowicz-Przybycień obtaining an index under two. As it was mentioned before, the inclusion of books and book chapters as objects of study probably caused these scores, but a greater communication and collaboration with national and international authors should be promoted for increasing the amount and quality of papers focused on jujutsu (KYVIK; REYMERT, 2017). The establishment of a research group about jujutsu in the University School of Physical Education in Krakow (Table 4), should be understood as a way for promoting and strengthening national collaboration. This research group consisted of Ambroży and Sterkowicz-Przybycień, who have been publishing and collaborating during the last decade. These results are reflecting Polish jujutsu research is an emerging field of knowledge in comparison with other martial arts or countries, in which communication among scholars should be strengthened for increasing the amount of collaborators and extending collaboration networks, following the same way of taekwondo or judo research.

Finally, Polish jujutsu documents were principally disseminated in eight journals, collecting them almost half of total documents and confirming Bradford's law of scattering that there are a few very productive periodicals (DIODATO, 2012; SALINI, 2016). The existence of four martial arts and combat sports-oriented journals within these top sources, all of them edited or published in Poland, should be also highlighted. The interest of Polish scholars and academics on martial arts and combat sports, together with the great number of studies performed on this topic are probably the causes explaining the edition of these journals, becoming Poland the most represented country within martial arts and combat sports journals worldwide (CYNARSKI; REGULI, 2014; GUTIÉRREZ-GARCÍA et al., 2018).

The development and characteristics of Polish jujutsu documents is also in accordance with the scientificization of martial arts, represented on the appearance of scientific journals, with nine out of 12 of them published from 2000 onwards, the creation of the International Association of Judo Researchers in 2006 (INTERNATIONAL ASSOCIATION OF JUDO RESEARCHERS, 2021) or the International Martial Arts and Combat Sports Scientific Society in 2010 (CYNARSKI; REGULI, 2014) among others and the celebration of their own scientific congresses (BAZK; KULASA, 2007; INTERNATIONAL ASSOCIATION OF JUDO RESEARCHERS, 2021).

Regarding the social and cultural development of martial arts In Poland, jujutsu was mainly practiced and described as self-defence, judo self-defence or defensive holds until the 1970s. Even in the interwar period, there were publications pointing out to jujutsu as valuable for military training, physical education and health (PAWEŁEK, 1929). After World War II, judo was developed in military and police centers and promoted as an Olympic sport that took part in international competitions. It was only after 1970 that karate appeared in Poland, and then gradually other Asian martial arts. Since 1989, the year of systemic and political change, various types of martial arts have appeared, becoming jujutsu one of the many martial arts practiced in Poland.

Sciences of physical culture in Poland are focused on the development of sport, especially Olympic disciplines. Few studies of martial arts, including jujutsu, 
go beyond the biomedical approach to sport. Polish authors carry out research on jujutsu and other martial arts threading several topics, such as a description of a littleknown figure of physical culture (PIASECKI, 1904a, 1904b, 1904c), emphasizing their utilitarian and health values (HANCOCK; KŁOŚNIK, 1907, 1909), describing their history and process of institutionalization (CYNARSKI; BAJOREK, 2011), or presenting the schooling process of sport jujutsu (STERKOWICZ; AMBROŻY, 2003). Moreover, since its inception in 2000, Ido Movement for Culture is widening these approaches for presenting humanistic views of martial arts.

In comparison to taekwondo and judo scientific production, despite they were only focused on articles, their top journals only included one martial arts and combat sports-oriented source (Archives of Budo) and most of them were related to Sport Sciences, approaching from Life Sciences. Several causes could explain this situation. Firstly, the time span of taekwondo (PÉREZ-GUTIÉRREZ et al., 2017) and judo (PESET et al., 2013) studies finished in 2016 and 2011 respectively, limiting the appearance of those recently created journals. Thus, the Journal of Combat Sports and Martial Arts was first published in 2010 (INDEX COPERNICUS, 2021), while Archives of Budo Science of Martial Arts and Extreme Sports appeared in 2013 (ARCHIVES OF BUDO SCIENCE OF MARTIAL ARTS AND EXTREME SPORTS, 2021), so they did not compiled a great number of articles or even existed when those studies were performed. Secondly, the predominance of Life Sciences in taekwondo (PÉREZ-GUTIÉRREZ et al., 2015; PÉREZ-GUTIÉRREZ et al., 2017) and judo (PESET et al., 2013) scientific production as well as the physiological orientation of their top authors could explain the use of Sport Sciences- and Life Sciences-oriented journals for disseminating their results. Despite Life Sciences was also the main field of science represented in our results, the most developed self-defence orientation of jujutsu (CYNARSKI, 2012) could be fundamental for the authors to select martial arts and combat sports-oriented journals. Thirdly, our results are due to the national scope of the present study, which presents and enhances the Polish martial arts and combat sports journals.

Ido Movement for Culture and Archives of Budo were the main sources of information, collecting both $25.81 \%$ of total documents. The history and international indexation of these journals explain their relevance for disseminating Polish jujutsu articles. The first volume of Ido Movement for Culture appeared in 2000 and it is currently indexed in Scopus and the Emerging Sources Citation Index from the Web of Science (IMC JOURNAL, 2021b). Archives of Budo was firstly edited in 2005 and its indexation includes Scopus and the Science Citation Index Expanded from the Web of Science (ARCHIVES OF BUDO, 2021). Moreover, the relevance of Archives of Budo within taekwondo (PÉREZ-GUTIÉRREZ et al., 2015; PÉREZ-GUTIÉRREZ et al., 2017), judo (PESET et al., 2013) and Olympic combat sports literature (FRANCHINI; GUTIERREZ-GARCIA; IZQUIERDO, 2018) was due to these studies developed their data mining solely in the Web of Science. Future studies focused on martial arts and combat sports should include other databases such as ERIC, Pubmed, Scopus or SPORTDiscus for widening information retrieval and offering a larger overview. 


\section{CONCLUSIONS}

The present study retrieved 123 Polish jujutsu documents published from 1906 to 2020 . During the $20^{\text {th }}$ century, there existed a predominance of jujutsu books, with a technical character, written by single authors from a Life Sciences approach. During the $21^{\text {st }}$ century, scientific articles about jujutsu were the main type of document. The interest of Polish scholars and academics on martial arts and combat sports in general, and jujutsu in particular, the establishment of institutions such as the Polish Ju-Jitsu Association, as well as the appearance of scientific journals on martial arts and combat sports probably triggered this scientific production. Like a typical aspect of science, collaboration among authors increased, especially within the most productive academics. Moreover, the relevance of Life Sciences approach was also extended to other fields of knowledge, strengthening the understanding about jujutsu.

Regarding the most productive authors, Cynarski is the leading researcher, exhibiting the more extensive collaboration network. The scarce number of collaborators shown by some of the most productive scholars was because they were trainers and teachers writing books about jujutsu fundamentals. Nevertheless, the collaboration index of these authors was lower than in other martial arts and combat sports studies, so national and international collaboration should be strengthened in accordance with the scientific domain for increasing their productivity as well as improving their studies' quality.

Finally, the main sources for the dissemination of jujutsu documents included four martial arts and combat sports journals, all of them edited or published in Poland, reflecting Polish scholars' interest on this topic. Ido Movement for Culture and Archives of Budo were the most important journals, collecting a quarter of the total production due to their history and international indexation.

\section{REFERENCES}

ANDRADE, David C.; LÓPEZ, Boris A.; RAMÍREZ-CAMPILLO, Rodrigo; BELTRÁN, Ana R.; RODRÍGUEZ, Roxana P. Bibliometric analysis of South American research in sports science from 1970 to 2012. Motriz, v. 19, n. 4, p. 783-791, 2013. DOI: http://dx.doi.org/10.1590/ S1980-65742013000400017.

ARCHIVES OF BUDO. Home Page. Available at: http://archbudo.com/. Accessed on: Jan. 15, 2021.

ARCHIVES OF BUDO SCIENCE OF MARTIAL ARTS AND EXTREME SPORTS. Home Page. Available at: http://smaes.archbudo.com/. Accessed on: Jan.15, 2021.

BĄK, Robert; KULASA, Jerzy. 1st Word Scientific Congress of Combat Sports and Martial Arts (22-24 September 2006) and "Rzeszow Declaration". Archives of Budo, v. 3, p. 86-89, 2007. Available at: http://archbudo.com/view/abstracts/issue id/369. Accessed on: June 30, 2021. 
BORDONS, María; GÓMEZ, Isabel. Collaboration networks in Science. In: CRONIN, Blaise; ATKINS, Helen B. The Web of Knowledge: A Festschrift in Honor of Eugene Gardfield. Medford, NJ: American Society for Information Science, 2000. p. 197-213.

BRONIKOWSKI, Michal. Where is physical and health education heading in Poland? In: CHIN, Ming-Kai; EDGINTON, Christopher R. Physical Education and Health: Global Perspectives and Best Practice. Urbana, IL: Sagamore, 2014. p. 369-381.

ČIHOUNKOVÁ, Jitka; REGULI, Zdenko. A Search of literature on karate published in the Czech Republic. In: CYNARSKI, Wojciech J. Selected areas of intercultural dialogue in martial arts. Rzeszow: Wydawnictwo Uniwersytetu Rzeszowskiego, 2011. p. 101-109.

CRAIG, Darrell M. Japan's Ultimate Martial Art: Jujitsu before 1882. The classical Japanese art of self-defence. Boston: Tuttle Publishing, 1995.

CYNARSKI, Wojciech J. Bibliografia dalekowschodnich sztuk walki - analiza treści $=$ Far East martial arts bibliography - content analysis. Ido Movement for Culture, v. 2, p. 15-25, 2001.

CYNARSKI, Wojciech J. Jūjutsu yesterday and today. From research on the institutionalization of martial arts. Ido Movement for Culture. Journal of Martial Arts Anthropology, v. 12, n. 3, p. 10-18, 2012. Available at: http://imcjournal.com/index.php/en/ volume-xii-2012/contents-number-3/345-jujutsu-yesterday-and-today-from-research-on-theinstitutionalization-of-martial-arts. Accessed on: January 15, 2021.

CYNARSKI, Wojciech J. Literatura dotycząca jūjutsu i samoobrony w PRL = Literature on jūjutsu and self-defence in the Polish People's Republic. In: ZABORNIAK, S.; OBODYNSKI, M. (eds). Z tradycji kultury fizycznej w Polsce po Il wojnie światowej. Rzeszów: Rzeszów University, 2008. p. 82-92.

CYNARSKI, Wojciech J. Martial Arts and Combat Sport: Towards the General Theory of Fighting Arts. Gdańsk: Wydawnictwo Naukowe Katedra, 2019.

CYNARSKI, Wojciech J. Opinia biegłego dotycząca formuł sportowych w jūjutsu = An expert's opinion on sports formulas in jūjutsu. Ido Movement for Culture, v. 7, p. 182-184, 2007. Available at: http://imcjournal.com/index.php/en/volume-vii-2007/contents-vol-vii/814an-expert-s-opinion-on-sports-formulas-in-jujutsu. Accessed on: January 15, 2021.

CYNARSKI, Wojciech J. Polish achievements in the theory of physical education and new directions. Ido Movement for Culture. Journal of Martial Arts Anthropology, v. 14, n. 2, p. 1-14, 2014. DOI: 10.14589/ido.14.2.1. Available at http://imcjournal.com/index.php/en/ volume-xiv-2014/contents-number-2/136-polish-achievements-in-the-theory-of-physicaleducation-and-new-directions. Accessed on: June 30, 2021.

CYNARSKI, Wojciech J. Sztuki walki budo $\mathbf{w}$ kulturze Zachodu = Martial Arts Budo in Western Culture. Rzeszów: WSP, 2000.

CYNARSKI, Wojciech J. Teoria i praktyka dalekowschodnich sztuk walki w perspektywie europejskiej. Rzeszów: Rzeszów University, 2004.

CYNARSKI, Wojciech J.; BAJOREK, Wojciech. Institutionalization of the jujutsu martial art in Poland - the problem of teaching qualifications. Ido Movement for Culture. Journal of Martial Arts Anthropology, v. 11, n. 4, p. 57-61, 2011. Available at: http://imcjournal.com/ index.php/en/volume-xi-2011/contents-number-4/487-institutionalization-of-the-jujutsumartial-art-in-poland-the-problem-of-teaching-qualifications. Accessed on: January 15, 2021. 
CYNARSKI, Wojciech J.; REGULI, Zdenko. Martial arts science institutionalisation: specialized scientific periodicals. Ido Movement for Culture. Journal of Martial Arts Anthropology, v. 14, n. 1, p. 54-62, 2014. DOI: 10.14589/ido.14.1.5. Available at: http:// imcjournal.com/index.php/en/volume-xiv-2014/contents-number-1/123-martial-arts-scienceinstitutionalisation-specialized-scientific-periodicals. Accessed on: June 30, 2021.

CYNARSKI, Wojciech J.; SIEKANSKI, Leszek. Essay on the Polish Ju-Jitsu Association's history (1993-2018). Ido Movement for Culture. Journal of Martial Arts Anthropology, v. 19, n. 2, p. 4-11, 2019. DOI: https://doi.org/10.14589/ido.19.2.2. Available at: http://imcjournal. com/index.php/en/volume-xix-2019/contents-number-2/1468-essay-on-the-polish-ju-jitsuassociation-s-history-1993-2018. Accessed on: January 15, 2021.

CYNARSKI, Wojciech J.; SKOWRON, Joanna. An analysis of the conceptual language used for the general theory or martial arts - Japanese, Polish and English terminology. Ido Movement for Culture. Journal of Martial Arts Anthropology, v. 14, n. 3, p. 49-66, 2014. DOI: https://doi.org/10.14589/ido.14.3.7. Available at: http://imcjournal.com/index.php/en/ volume-xiv-2014/contents-number-3/175-an-analysis-of-the-conceptual-language-used-forthe-general-theory-of-martial-arts-japanese-polish-and-english-terminology. Accessed on: January 15, 2021.

DIODATO, Virgil P. Dictionary of bibliometrics. New York: Routledge, 2012.

DO KIM, Gun; PIETER, Willy. Isokinetic leg strength in adolescent Malaysian recreational taekwondo practitioners. Ido Movement for Culture. Journal of Martial Arts Anthropology, v. 20, n. 1, p. 49-53, 2020. DOI: https://doi.org/10.14589/ido.20.1.6. Available at: http:// imcjournal.com/index.php/en/volume-xx-2020/contents-number-1/1549-isokinetic-legstrength-in-adolescent-malaysian-recreational-taekwondo-practitioners. Accessed on: January 15, 2021.

DO KIM, Gun; PIETER, Willy; BERCADES, Luigi T. Determinants of performance in university taekwondo athletes. Science and Sports, v. 33, n. 1, p. e19-24, 2018. DOI: https://doi.org/10.1016/j.scispo.2017.08.005. Available at: https://www.sciencedirect.com/ science/article/pii/S0765159717301764?via\%3Dihub. Accessed on: January 15, 2021.

FRANCHINI, Emerson; DUNN, Emily; TAKITO, Monica Y. Reliability and usefulness of time-motion and physiological responses in simulated judo matches. Journal of strength and conditioning research, v. 34, n. 9, p. 2557-2564, 2020. DOI: https://doi. org/10.1519/JSC.0000000000002727. Available at: https://journals.Iww.com/nsca-jscr/ Abstract/2020/09000/Reliability_and_Usefulness_of_Time_Motion_and.20.aspx. Accessed on: January 15, 2021.

FRANCHINI, Emerson; GUTIERREZ-GARCIA, Carlos; IZQUIERDO, Eugenio. Olympic combat sports research output in the Web of Science: A sport sciences centered analysis submission. Ido Movement for Culture. Journal of Martial Arts Anthropology, v. 18, n. 3, p. 21-27, 2018. DOI: https://doi.org/10.14589/ido.18.3.4. Available at: http://imcjournal.com/ index.php/en/volume-xviii-2018/contents-number-3/1365-olympic-combat-sports-researchoutput-in-the-web-of-science-a-sport-sciences-centered-analysis. Accessed on: January 15, 2021.

GREEN, Thomas A.; SVINTH, Joseph R. Martial Arts of the World: An Encyclopedia of History and Innovation. Santa Barbara (CA): ABC-CLIO, 2010.

GRZEGORZ, Roman; WALENDOWICZ, Marcin. The History of Ju-Jitsu in Poland 19041939. Glogow: International Modern Ju-Jitsu Federation, 2008. 
GUSENBAUER, Michael; HADDAWAY, Neal R. Which academic search systems are suitable for systematic reviews or meta-analyses? Evaluating retrieval qualities of Google Scholar, PubMed, and 26 other resources. Research Synthesis Methods, v. 11, n. 2, p. 181-217, 2020. DOI: 10.1002/jrsm.1378.

GUTIÉRREZ-GARCÍA, Carlos; CYNARSKI, Wojciech J.; CRÉE, Carl D. et al.. In which journals can I publish my research on martial arts and combat sports? An up-to-date approach. WORLD SCIENTIFIC CONGRESS OF COMBAT SPORTS AND MARTIAL ARTS, 4., and IMACSSS INTERNATIONAL CONFERENCE, 7, 2018. Abstract Book, Rzeszów: IMACSSS, 2018. p. 39-41. Available at: https://biblio.ugent.be/publication/8578479/ file/8578481.pdf. Accessed on: June, 29, 2021.

GUTIÉRREZ-GARCÍA, Carlos; PÉREZ-GUTIÉRREZ, Mikel. A study of the earliest books on martial arts published in Spanish. Ido Movement for Culture, v. 9, p. 11-27, 2009a. Available at: http://imcjournal.com/index.php/en/volume-ix-2009/contents-volume-ix/589-astudy-of-the-earliest-books-on-martial-arts-published-in-spanish. Accessed on: January 15, 2021.

GUTIÉRREZ-GARCÍA, Carlos; PÉREZ-GUTIÉRREZ, Mikel. Study on scientific production in martial arts in Spain from 1990 to present. In: CYNARSKI, Wojciech J. Martial Arts and Combat Sports: Humanistic Outlook. Rzeszow: Wydawnictwo Uniwersytetu Rzeszowskiego, 2009b. p. 90-115.

HAESENDONCK, François Van; WOJCIECHOWSKI, Bernard. Ju-jitsu. [1], Pas biały = Jujitsu. [1], White belt. Warszawa: Sport i Turystyka, 1960a.

HAESENDONCK, François Van; WOJCIECHOWSKI, Bernard. Ju-jitsu. [2], Pas żółty = Jujitsu. [2], Yellow belt. Warszawa: Sport i Turystyka, 1960b.

HAESENDONCK, François Van; WOJCIECHOWSKI, Bernard. Ju-jitsu. [3], Pas pomarańczowy = Ju-jitsu. [3], Orange belt. Warszawa: Sport i Turystyka, 1961a.

HAESENDONCK, François Van; WOJCIECHOWSKI, Bernard. Ju-jitsu. [4], Pas zielony = Ju-jitsu. [4], Green belt. Warszawa: Sport i Turystyka, 1961b.

HAESENDONCK, François Van; WOJCIECHOWSKI, Bernard. Ju-jitsu. [5], Pas niebieski = Ju-jitsu. [5], Blue belt. Warszawa: Sport i Turystyka, 1961c.

HANCOCK, Harrie I.; KŁOŚNIK, Zygmunt. Dżiu-dżicu czyli Źródło zdrowia, siły i zręczności $=$ Jiu-jitsu, or The Source of Health, Strength and Dexterity. Lwów; Warszawa: J. Maniszewski; E. Wende, 1909.

HANCOCK, Harrie I.; KŁOŚNIK, Zygmunt. Źródło zdrowia, siły i zręczności = The Source of Health, Strength and Dexterity. Lwów; Warszawa: Maniszewski i Meinhart; E. Wende, 1907.

INTERNATIONAL ASSOCIATION OF JUDO RESEARCHERS. Our history. Available at: http://judoresearch.org/about-us/historyl. Accessed on: June 30, 2021

INDEX COPERNICUS. ICI World of Journals. Journal of Combat Sports and Martial Arts. Available at: https://journals.indexcopernicus.com/search/details?id=17978 . Accessed on: January 15, 2021.

INTERNATIONAL JUDO FEDERATION. History and Culture. Available at: https://www.ijf. org/history. Accessed on: April 01, 2021.

IMC JOURNAL. About Ido Movement for Culture. Journal of Martial Arts Anthropology. Available at: http://www.imcjournal.com/index.php/en/about-imc-journal. Accessed on: January 15, 2021a. 
IMC JOURNAL. Indexations. Available at: http://www.imcjournal.com/index.php/en/ indexations. Accessed on: January 15, 2021b.

JEZIOROWSKI, Henryk; OSMOLSKI, Władysław. Walka wręcz: jiu-jitsu = Hand-to-hand combat: jiu-jitsu. Warszawa: Wojskowy Instytut Naukowo-Wydawniczy, 1923.

KYVIK, Svein; REYMERT, Ingvild. Research collaboration in groups and networks: differences across academic fields. Scientometrics, v. 113, n. 2, p. 951-967, 2017. DOI: https://doi.org/10.1007/s11192-017-2497-5. Available at: https://link.springer.com/ article/10.1007\%2Fs11192-017-2497-5. Accessed on: January 15, 2021.

LÓPEZ LÓPEZ, Pedro. Introducción a la bibliometría. Valencia: Promolibro, 1996.

LUCZAK, Maciej. A review of major Polish scholarly studies on fencing in the $21^{\text {st }}$ century. Ido Movement for Culture. Journal of Martial Arts Anthropology, v. 15, n. 2, p. 1-9, 2015. DOI: https://doi.org/10.14589/ido.15.2.1. Available at: http://imcjournal.com/index.php/en/ volume-xv-2015/contents-number-2/43-a-review-of-selected-polish-research-studies-oncompetitive-fencing. Accessed on: January 15, 2021.

NITOBE, Inazo. Bushido - dusza Japonii $=$ Bushido - the Soul of Japan. Lvov-Warsaw: $\mathrm{H}$. Altenberg, E. Wende, 1904.

OKSZYC, A. Japonia i Japończycy = Japan and the Japanese. Warsaw: M. Arcta, 1904.

OSAKA, Nimura. Dżiu-Dżitsu: jak obronić się przed napaścią uliczną (japoński system samoobrony). Warszawa: Wiedza Współczesna, 1935.

OUERGUI, Ibrahim; FRANCHINI, Emerson; SELMI, Okba et al.. Relationship between perceived training load, well-being indices, recovery state and physical enjoyment during judo-specific training. International Journal of Environmental Research and Public Health, v. 17, n. 20, p. 1-8, 2020. DOI: https://doi.org/10.3390/ijerph17207400. Available at: https://www.mdpi.com/1660-4601/17/20/7400. Accessed on: January 15, 2021.

PALAZÓN, María Ángeles; ORTEGA, Enrique; GARCÍA-ANGULO, Antonio. Análisis bibliométrico de la producción científica en el fútbol sala. SporTK: Revista Euroamericana de Ciencias del Deporte, v. 4, n. 2, p. 19-24, 2015.

PAWEŁEK, Alojzy. Centralna Wojskowa Szkoła Gimnastyki i Sportów w Poznaniu: 19211929 = Central Military School of Gymnastics and Sports in Poznań: 1921-1929. Poznań: CWSGiS, 1929.

PÉREZ-GUTIÉRREZ, Mikel; COBO-CORRALES, Carlos. Surfing scientific output indexed in the Web of Science and Scopus (1967-2017). Movimento (Porto Alegre), v. 26, p. e26015, 2020. DOI: https://doi.org/10.22456/1982-8918.94062. Available at: https://seer.ufrgs.br/ Movimento/article/view/94062. Accessed on: Jan. 15, 2021.

PÉREZ-GUTIÉRREZ, Mikel; COBO-CORRALES, Carlos; IZQUIERDO-MACÓN, Eugenio. Chilean sport sciences scientific production indexed in the Web of Science (19812016). Motriz, v. 24, n. 1, p. e1018148, 2018. DOI: http://dx.doi.org/10.1590/S19806574201800010008. Available at: https://www.scielo.br/pdf/motriz/v24n1/1980-6574-motriz24-01-e1018148.pdf. Accessed on: January 15, 2021.

PÉREZ-GUTIÉRREZ, Mikel; GUTIÉRREZ-GARCÍA, Carlos. Bibliometric analysis of karate monographs in Spain (1963-2006). In: CYNARSKI, Wojciech J. Martial Arts and Combat Sports: humanistic outlook. Rzeszow: Wydawnictwo Uniwersytetu Rzeszowskiego, 2009. p. 116-126. 
PÉREZ-GUTIÉRREZ, Mikel; GUTIÉRREZ-GARCÍA, Carlos. Description of the methodology used for the preparation of an annotated bibliography about Asian martial arts monographs. In: CYNARSKI, Wojciech J. Selected areas of intercultural dialogue in martial arts. Rzeszow: Wydawnictwo Uniwersytetu Rzeszowskiego, 2011. p. 110-122.

PÉREZ-GUTIÉRREZ, Mikel; GUTIÉRREZ-GARCÍA, Carlos. Estudio bibliométrico sobre las monografías de artes marciales publicadas en España (1906-2006). Revista de Artes Marciales Asiáticas, v. 3, n. 4, p. 22-33, 2008. Available at: http://revistas.unileon.es/index. php/artesmarciales/article/viewFile/387/341. Accessed on: January 15, 2021.

PÉREZ-GUTIÉRREZ, Mikel; GUTIÉRREZ-GARCÍA, Carlos; ESCOBAR-MOLINA, Raquel. Terminological recommendations for improving the visibility of scientific literature on martial arts and combat sports. Archives of Budo, v. 7, n. 3, p. 159-166, 2011. Available at: https://www.researchgate.net/publication/269630083 Terminological recommendations for_improving the visibility of scientific literature on martial_arts and combat_sports. Accessed on: January 15, 2021.

PÉREZ-GUTIÉRREZ, Mikel; LAGOS-HERNÁNDEZ, Roberto I.; IZQUIERDO-MACÓN, Eugenio. Sport Sciences' scientific production published in Chile (1912-2014): a bibliometric approach. Movimento, v. 22, n. 4, p. 1121-1136, 2016. DOI: https://doi.org/10.22456/19828918.64654. Available at: https://seer.ufrgs.br/Movimento/article/view/64654/39721. Accessed on: January 15, 2021.

PÉREZ-GUTIÉRREZ, Mikel; VALDES-BADILLA, Pablo; GÓMEZ-ALONSO, María Teresa; GUTIÉRREZ-GARCÍA, Carlos. Bibliometric analysis of taekwondo articles published in the Web of Science (1989-2013). Ido Movement for Culture. Journal of Martial Arts Anthropology, v. 15, n. 3, p. 8-21, 2015. DOI: http://dx.doi.org/10.14589/ido.15.3.4. Available at: http://imcjournal.com/index.php/en/volume-xv-2015/contents-number-3/74-bibliometricanalysis-of-taekwondo-articles-published-in-the-web-of-science-1989-2013. Accessed on: January 15, 2021.

PÉREZ-GUTIÉRREZ, Mikel; VALDES-BADILLA, Pablo; GUTIÉRREZ-GARCÍA, Carlos; HERRERA-VALENZUELA, Tomás. Taekwondo scientific production published on the Web of Science (1988-2016): collaboration and topics. Movimento, v. 23, n. 4, p. 1325-1340, 2017. DOI: http://dx.doi.org/10.22456/1982-8918.75386.

PESET, Fernanda; FERRER-SAPENA, Antonia; VILLAMÓN, Miguel; GONZÁLEZ, LuisMillán; TOCA-HERRERA, José-Luis; ALEIXANDRE-BENAVENT, Rafael. Scientific literature analysis of Judo in Web of Science. Archives of Budo, v. 9, n. 2, p. 81-91, 2013. Available at: http://archbudo.com/view/abstract/id/10549. Accessed on: January 15, 2021.

PIASECKI, Eugeniusz. Wychowanie fizyczne $w$ Japonii = The Physical Education in Japan. Muzeum, Lwów, v. 20, p. 1005-1008, 1904a.

PIASECKI, Eugeniusz. Wychowanie fizyczne $w$ Japonii = The Physical Education in Japan. Przewodnik Gimnastyczny Sokół, v. 10, p. 74-75, 1904b.

PIASECKI, Eugeniusz. Wychowanie fizyczne $\mathrm{w}$ Japonii $=$ The Physical Education in Japan. Przegląd Pedagogiczny, v. 20, p. 237-239, 1904c.

PRICE, Derek J. de Solla. Little Science, Big Science... and Beyond. New York: Columbia University Press, 1986.

PRIETO, Jaime; GÓMEZ, Miguel-Ángel; SAMPAIO, Jaime. Revisión bibliométrica de la producción científica en balonmano. Cuadernos de Psicología del Deporte, v. 15, n. 3, p. 145-154, 2015. Available at: https://revistas.um.es/cpd/article/view/244561. Accessed on: January 15, 2021. 
SALINI, Silvia. An introduction to Bibliometrics. In: GREENFIELD, Tony; GREENER, Sue. Research Methods for Postgraduates. Chichester, UK; Hoboken, NJ: John Wiley \& Sons, 2016. p. 130-143.

SIMPLE KNOWLEDGE ORGANIZATION SYSTEM. UNESCO nomenclature for fields of science and technology. Available at: http://skos.um.es/unesco6/?l=en. Accessed on: January 15, 2021.

STERKOWICZ, Stanisław; AMBROŻY, Tadeusz. Ju-jitsu sportowe: process szkolenia (podręcznik trenera) $=$ Sport Ju-jitsu: schooling process (coach's guidelines). Kraków: European Association for Security, 2003.

SZAJNA, Gabriel. Polskie piśmiennictwo szermiercze w XIX i XX wieku = Polish fencing bibliography in 19th and 20th century. Ido Movement for Culture, v. 7, n. p. 65-75, 2007. Available at: http://imcjournal.com/index.php/en/volume-vii-2007/contents-vol-vii/781-polishfencing-bibliography-in-19th-and-20th-century. Accessed on: January 15, 2021.

VALENCIANO VALCÁRCEL, Javier; DEVÍS-DEVÍS, José; VILLAMÓN, Miguel; PEIRÓVELERT, Carmen. La colaboración científica en el campo de las Ciencias de la Actividad Física y el Deporte en España. Revista española de documentación científica, v. 33, n. 1, p. 90-105, 2010. DOI: https://doi.org/10.3989/redc.2010.1.726. Available at: http://redc. revistas.csic.es/index.php/redc/article/view/527/585. Accessed on: January 15, 2021.

VIT, Michal; REGULI, Zdenko. Systematized review of Czech literature on combatives and self-defence. In: CYNARSKI, Wojciech J. Selected areas of intercultural dialogue in Martial Arts. Rzeszow: Wydawnictwo Uniwersytetu Rzeszowskiego, 2011. p. 83-100.

WANG, Lei; THIJS, Bart; GLÄNZEL, Wolfgang. Characteristics of international collaboration in sport sciences publications and its influence on citation impact. Scientometrics, v. 105, p. 843-862, 2015. DOI: https://doi.org/10.1007/s11192-015-1735-y. Available at: https://link. springer.com/article/10.1007/s11192-015-1735-y. Accessed on: January 15, 2021.

WEULERSSE, Georges. Współczesna Japonia = The Contemporary Japan. Warsaw: Gebethner i Wolff, 1904. 
Resumo: O objetivo foi realizar uma análise bibliométrica das publicações polonesas sobre jiu-jítsu com foco nos aspectos de produtividade, assuntos e colaboração. Assim, a Biblioteca Nacional da Polônia, a Base de Revistas Científicas Polonesas, Web of Science e Scopus foram consultados. Os resultados foram filtrados e exportados para o Excel 2016 para análise estatística. Os documentos poloneses sobre jiu-jítsu chegaram a 123 publicados entre 1906 e 2020. Ciências da Vida foi o campo mais representado, enquanto a colaboração prevaleceu durante a última década. Cynarski foi o autor mais produtivo, enquanto Wojdat teve a maior taxa de colaboração. Ido Movement for Culture foi o principal divulgador dessas publicações. Em conclusão, as publicações polonesas sobre jiu-jítsu mostraram durante o século XX uma predominância de livros técnicos escritos por autores individuais a partir de uma abordagem das Ciências da Vida, enquanto os artigos científicos escritos em colaboração e também representando outras abordagens dominaram o século XXI.

Palavras chave: Bibliometria. Artes Marciais. Publicações. História.

Resumen: El objetivo fue realizar un análisis bibliométrico de las publicaciones polacas sobre jujutsu centrado en los aspectos de productividad, asuntos y colaboración. Así, se consultaron la Biblioteca Nacional de Polonia, la Base de Revistas Científicas Polacas, la Web of Science y Scopus. Los resultados fueron filtrados y exportados a Excel 2016 para el análisis estadístico. Los documentos polacos sobre jujutsu alcanzaron los 123, publicados entre 1906 y 2020. Ciencias de la Vida fue el campo más representado, mientras que la colaboración predominó durante la última década. Cynarski fue el autor más productivo, mientras que Wojdat obtuvo el índice de colaboración más alto. Ido Movement for Culture fue el principal divulgador de estas publicaciones. En conclusión, las publicaciones polacas sobre jujutsu mostraron, durante el siglo XX, un predominio de libros técnicos escritos por autores individuales desde un abordaje de las Ciencias de la Vida, mientras que los artículos científicos escritos en colaboración y representando también otros enfoques han dominado en el siglo XXI.

Palabras clave: Bibliometría. Artes Marciales. Publicaciones. Historia. 


\section{USE LICENSE}

This article is published for open access under the Creative Commons International Attributions 4.0 (CC BY 4.0) license, which allows use, distribution, and reproduction in any medium, provided that the original work is properly cited. More information at: https://creativecommons.org/licenses/by/4.0

\section{CONFLICT OF INTERESTS}

The authors have declared that this work involves no conflict of interest.

\section{AUTHORS' CONTRIBUTIONS}

Mikel Pérez-Gutiérrez: Conceptualization, Data curation, Methodology, Supervision, Writing - original draft, Writing - review \& editing

Paweł Świder: Conceptualization, Data curation, Investigation, Validation, Writing review \& editing

Jacek Kulpiński: Conceptualization, Data curation, Investigation, Validation, Writing - review \& editing

Wojciech J. Cynarski: Conceptualization, Data curation, Project administration, Supervision, Writing - original draft, Writing - review \& editing

\section{FUNDING}

This work no received financial support.

\section{HOW TO CITE}

PÉREZ-GUTIÉRREZ, Mikel; ŚWIDER, Paweł; KULPIŃSKI, Jacek; CYNARSKI, Wojciech J.. Polish publications on jujutsu (1906-2020): bibliometric analysis.

Movimento (Porto Alegre), v. 27, e27061, Jan./Dec. 2021. Available at: https:// seer.ufrgs.br/Movimento/article/view/111543. Accessed on [day] [abbreviated month]. [year]. DOI: https://doi.org/10.22456/1982-8918.111543

\section{EDITORIAL RESPONSIBILITY}

Alex Branco Fraga*, Elisandro Schultz Wittizorecki*, Ivone Job*, Mauro Myskiw*, Raquel da Silveira*

*Federal University of Rio Grande do Sul, School of Physical Education, Physiotherapy and Dance, Porto Alegre, RS, Brazil. 